\title{
The Economic Integration of the Turkic States and Latin Alphabet
}

\author{
Aidos Saduakassov \\ Associate professor of the International relations department of L.N. Gumilyov Eurasian \\ National University, Astana 010000, Kazakhstan
}

\begin{abstract}
As core of Turkic integration the humanitarian component traditionally acts where the general alphabet is the main question. Latin alphabet may be a push in new integration process between Turkic states in such spheres as culturalhumanitarian and political-economical cooperation.

The present paper presents the results of analysis of problem on economic integration of the Turkic states by means of Latin graphics and the author puts forward a number of constructive recommendations on the formation of the all-Turkic alphabetic space.
\end{abstract}

Keywords: the Latin alphabet, an economic integration, the Turkic States, the Turkic business council, the customs procedure.

\section{Introduction}

The Turkic world occupies a considerable part of the Eurasian continent. The demographic data testifies that approximately 200 million of people now are of a Turkic origin united by ethnogenesis, mentality, language, history, the literature, spiritual and material culture, life style, traditions, customs and ceremonies of the people.

The last culturological researches testify that after overthrow of social ideal tendencies of consolidation of cultures on their ethno level have amplified. Similarity or, on the contrary, distinction of mentality and the history of the people became essential argument in their relations. It has led to the proclamation to a new cultural slogans regarding as of paramount importance ethnic, language and historical affinity of the people.

\section{Alphabet as the Instrument of Economical Integration}

It is known that now for cultural development the mass audience is necessary. All modern media and entertainments: journals, literature, cinema, television, computer games, the Internet sites, show business develop under market laws and demand a mass edition or the mass consumer to provide profit of the publisher and the author (or at least to pay expenses on the edition). For language work such circulation can be provided only at a certain population using this language. At number less certain «critical weight» in such language isn't present commercial sense to release books, films, audiodisks, computer games and programs or create of Internet sites. And without it language is doomed on a survival, on gradual dying off and absorption by other stronger languages. Also as at division of kernels of uranium into development of chain reaction the critical mass of uranium is required, for language development (development, instead of existence) is required critical 
population. What this critical number - a question disputable, but, for certain, is estimated in millions, or even in tens of millions. For example, the Kazakhstan film director Ardak Amirkulov argues that profitable production and hire of films needs about 50 million population. Taking into account that books are read by a smaller part of people, it is possible to the same about the literature.

One of fundamental problems of practical realization of a principle of development in system of writing of mankind is that the maximum form of development of writing is the alphabetic writing, however the alphabet in many countries is not applied. In them hieroglyphic or syllabic writing is applied. In China with the population more than 1300 million person is applied hieroglyphic writing. In Japan with the population more than 125 million person and both national states of the Korean nation having an aggregate number of the population more of 65 million the person, is applied the mixed writing -hieroglyphic and syllabic simultaneously. Thus, the fourth part of mankind applies hieroglyphic writing which demands huge expenses of time and not creative intellectual efforts for achievement of isomorphism of oral and written forms of language in intelligence studying language in this or that form.

The affinity of Turkic languages creates huge possibilities which should are used before the Turkic people, but eventually are lost. Creation and introduction general Turkic alphabet on the basis of a Latin drawing, would give to the Turkic people following advantages:

1. Expansion of possibility of Interturkic dialogue.

2. Storage and using the information of all Turkic people.

3. Growth of the importance of each Turkic language.
4. This alphabet unlike other regional alphabets would be the most suitable to Turkis.

5. Studying of this alphabet would be much easier, than studying of other regional alphabets.

6. Achievement of economy of resources, as owing to the decision of communication and information problems, and owing to rather small expenses for studying of the given alphabet.

7. Development of cultural-spiritual and political-economical integration in the conditions of globalization.

According to British researcher Mark Dickens, Bolsheviks could have created common-Turkic language in USSR in 1920 -s in the frame of the policy of merging of peoples. But this contradicted the interests of Bolsheviks to disunite the Turkic community, that's why they carried out policy of not simply creation of separate Turkic languages but emphasizing the differences between them. ${ }^{1}$

As a result of alphabetic reforms carried out in 20-40 years of the XX century the Soviet Union there was a division of the Turkic world into more than 30 literary languages. Also it is reform for the first time it was tested in Azerbaijan.

\section{The Role of Latin Alphabet in Settling a Modern Geoeconomic Situation of the Turkic States}

In the end of XX-century with the growth of ethnical self-consciousness of the Turkic peoples and with the emergence of independent Turkic states, the idea of necessity of convergence and developing cooperation between Turkic peoples gained a new impulse, though according to the above-mentioned reasons it did not become popular. However the following premises for integration of the Turkic peoples make the integration intensification indispensable and a wider 
spread of the idea amongst the Turkic public expected:

1. Requirement of joint activity on conservation and development of cultural and spiritual potential of the Turkic world. 2. Demand in consolidation of Turkic region's potentials in terms of regionalization of the whole world.

3. Requirement of centralized vindication of interests of the Turkic world subjects because of its situation in the center of Eurasia in the intersection of interests of the most powerful global actors

4. Community of geo-economic interests which particularly proceed from:

4.1 Location of the most of the Turkic countries inside the continent which is associated with the lack of access to sea and their being closed up on each other which results in necessity of the joint efforts for access to sea and to additional transport routes

4. 2 Location of the most of the Turkic countries at the centers of existing and potential routes of commodities and energy resources transportation and necessity of decreasing the barriers at these routes in order to encourage commodities and energy resources transportation at trans-Eurasian itineraries. $^{2}$

Basic problem of the Turkic world is also lack of the general borders. If Kazakhstan, Kyrgyzstan, Turkmenistan and Uzbekistan border with each other, from Azerbaijan they are separated by the Caspian Sea. Actually, Azerbaijan has not also bordered with Turkey. On a small site the autonomous republic Nakhichevan borders with a part of Azerbaijan which is however separated from the main territory of the country Armenia. Territorial dissociation of the main centers of the Turkic world stirs implementation of joint economic projects. Export of oil and gas resources with which Central Asia is rich could become their key link. However lack of regulation of legal status of the Caspian Sea and dispute concerning accessory of a number of sea fields between Azerbaijan and Turkmenistan stir implementation of these projects. As a result economic cooperation of the Turkic states obviously revolves. For example, commodity turnover of Kazakhstan with the Turkic countries in 2009 made only 3,7 billion dale or $3,8 \%$ of its total amount.

In recent years the idea of cultural, economic, and subsequently political association of the Turkic people received a new impulse. Turkic congresses and assemblies, the summits of heads of states are carried out, the Turkic Parliamentary Assembly is created, Nazarbayev's proposal on creation of the Union of the Central Asian states is discussed.

On October 13, 2011 the first meeting of Ministers of economy of Council of cooperation of the Turkic states took place in Astana. During a meeting of Ministers of economy, questions of improvement of investment climate, increase of an economic diversification, development of transport corridors and business were discussed. And on October 21, 2011 in Almaty passed the First summit of Council of cooperation of the Turkic states.

The chairman of the board of cooperation of the Turkic countries Nursultan Nazarbayev began the opening speech with pleasant news and an assignment. He gave to the secretariat a task to be prepared to the accession to the organization of Uzbekistan and Turkmenistan. This fact should increase even more potential of association of the brotherly world which includes about 40 nations and nationalities. Promotion of the general Turkic culture should become the Council stronghold.

One more important direction is, of course, trade-economical cooperation. Today, according to Nazarbayev, the 
volume of commodity circulation is far from real possibilities. It is necessary to eliminate barriers, to introduce innovations and to develop actively transport and transit potential.

\section{Conclusion}

Creation for mutual dialogue, training and information storage of the general Turkic alphabet is vital because by a question that or the Turkic community realizes the not used potential is and will achieve the above-stated advantages, or will continue to lose the most part of the potential caused by affinity of Turkic languages.

Irrespective of, how much successful there will be a project on creation and distribution of the general Turkic alphabet, with a view of use of advantages and potential of affinity of Turkic languages for the Turkic people it is possible to consider a minimum as the program:

1) Transition of all Turkic people on unified (or as much as possible close) to the schedule. This drawing can become only Latin, owing to following reasons:

1. Other two variants of a drawing Cyrillic and Arabian is a drawing of the countries in which Turkic are subject to the maximum danger of assimilation Russia, Iran and Afghanistan. The Latin drawing is means of overcoming of this factor.

2. The Latin drawing is the most widespread in the world and means of the maximum access to world information system.

3. The Latin drawing is a communication facility of Turkic languages with the Turkish language which is most developed and having most extensive sources of the information among Turkic languages.
2) coordination Adjustment in sphere of development of Turkic languages at which the maximum identity of entered terms should be provided, up to cancellation before the entered terms and to transition to the general words.

Regional economic-political integration of Turkic peoples can have either ethnic or not on principle ethnic character, because Turkic regions are related with economic and political ties to non-Turkic regions; in this connection isolationistic approach would result in losses for all interconnected regions. Together with this efforts on integration of all Turkic peoples within a single integration should be condition for such integration but the main condition is appropriate vindication of interests of the Turkic peoples within the integration particularly by means of consolidated vindication of interests of the Turkic peoples. ${ }^{3}$

Civilization character of integration is a basis to choose as an object of integration of not the Turkic states but the Turkic community and to intensify civil initiatives in the integration process, i.e. increase the role of non-governmental organizations.

\section{References}

[1] Dickens, M. Soviet Language Policy in Central Asia. http://www.oxuscom.com/langpolicy.htm, 1988.

[2] Khaydarov, M. Realization of Turkic Peoples' Language Potential. http://www.contact.az/docs/2011/Wa nt\%20to\%20Say/07147415en.htm, 2011.

[3] Khaydarov, M. The prospects of intensification of the Turkic world integration.

http://turk-media.info/?p=2621, 2011 